nghiệm y hơc giai đoạn 2016 - 2025.

2. Tiêu chuấn quốc gia TCVN ISO/IEC 17043 (2011). Đánh giá sư phù hợp - Yêu câuu chung đối với thử nghiệm thành thạo. Nhà xuất bản Hà Nôii, pp. $9-10$.

3. Hoàng Thị Hà Anh (2014). Xây dựng quy trình sản xuất mẫu ngoại kiểm đánh giá chất lượng phòng thí nghiêm huyết thanh hoc HIV, pp.48 - 53.

4. Tîêu chuẩn Việt Nam TCVN 7366:2011 (ISO GUIDE 34:2009) (2011). Yêu cầu chung về năng lực của nhà sản xuất mâu chuẩn, tr $17-18$.

5. Deom A, EI Aouad R, Heuck CC, Kumari S, Lewis SM, Uldall A \& World Health Organization
(1999). Requirements and guidance for external quality assessment schemes for health laboratories.

6. World Health Organization (WHO) (2004). External quality assessment of transfusion laboratory practice. Guidelines on establishing an EQA scheme in blood group serology. Geneva, pp. $27-33$.

7. Yu Y, Ma C, Feng $Q$, Chen $X$, et al (2013). Establishment and performance assessment of preparation technology of internal quality control products for blood transfusion compatibility testing, pp.3-6.

\title{
NGHIÊN CỨU KIẾN THỨC, THỰC HÀNH VỀ PHÒNG VÀ PHÁT HIÊN SỚM UNG THƯ VÚ Ở PHỤ NỮ 18-60 TUỔI TẠI THÀNH PHỐ CẦN THO' NĂM 2020
}

\author{
Nguyễn Minh Phương ${ }^{1}$, Lê Thị Kim Định², \\ Lê Thị Ngọc Thảnh ${ }^{2}$, Đinh Thanh Nam², Lê Thị Bích Tuyên ${ }^{2}$
}

TÓM TẮT

Đặt vấn đề: Kinh nghiệm của nhiều quốc gia trên thế giới cho thấy việc tầm soát và phát hiện càng sớm sẽ giúp điều trị bệnh càng đơn giản, hiệu quả điều trị càng cao, chi phí điều trị càng thấp. Như vậy, kiến thức và thực hành phòng và phát hiện sớm ung thư vú có ý nghĩa thực hiện đối với phụ nữ trong giai đoạn hiện nay. Mục tiêu: Xác định tỳ lệ kiến thức, thực hành đúng vể phòng và phát hiên sớm ung thư vú ở phụ nữ 18-60 tuổi tại thành phố Cần Thơ năm 2020. Đổi tượng và phướng pháp nghiên cứu: Nghiên cứu mô tả cắt ngang 286 phụ nữ 18-60 tuổi tại thành phố Cần Thơ từ tháng 5 năm 2020 đến tháng 9 năm 2020. Phỏng vấn trực tiếp để thu thập thông tin về kiến thức, thực hành về phòng và phát hiện sớm ung thư vú. Nội dung kiến thức gồm 3 nội dung chính là kiến thức về bệnh ung thư vú, các biện pháp phòng ngừa bệnh ung thư vú, kiến thức về phát hiện sớm ung thư vú. Xữ lý số liêu bằng phân mêm SPSS 20.0. Kêtt quả: tỷ lệ kiến thức và thực hành đúng về phòng và phát hiện sớm ung thư vú lần lượt là $32,5 \%$ và 19,9\%. Kết luâan: Kiến thức và thực hành về phòng và phát hiện sớm ung thư vú ở phư nữ 18-60 tuổi tại thành phố Cần Thơ khá thấp. Do đó, lãnh đạo Sở Y tế cần phối hợp bệnh viện có những biện pháp can thiệp phù hợp tăng cường kiến thức và thực hành về phòng và phát hiện sớm ung thư vú ở phụ nữ 18-60 tuổi.

Tư khóa: phòng và phát hiện sớm ung thư vú, kiến thức thực hành

\footnotetext{
${ }^{1}$ Trường Đại học Y dược Cần Thơ

²Bệnh viện Phụ sản thành phố Cần Thơ

Chịu trách nhiệm chính: Nguyễn Minh Phương

Email: nmphuong@ctump.edu.vn

Ngày nhận bài: 26.10.2020

Ngày phản biện khoa học: 26.11.2020

Ngày duyệt bài: 7.12.2020
}

\section{SUMMARY \\ KNOWLEDGE, PRACTICE OF PREVENTION AND DETECTION EARLY WITH BREAST CANCER IN WOMEN 18-60 YEARS AT CAN THO CITY IN 2020}

Background: Experience of many countries around the world shows that the earlier screening and detection will help to treat the disease as simple, the higher the effectiveness of treatment, the lower the cost of treatment. Thus, knowledge and practice of prevention and early detection of breast cancer have implications for women in the current period. Objectives: To determine the rate of knowledge and correct practice on breast cancer prevention and early detection among women 18-60 years old in Can Tho city in 2020. Objects and research methods: A cross-sectional study was conducted on 286 women 18-60 years in Can Tho city from May 2020 to September 2020. The variables of knowledge and practice for breast cancer prevention and early were interviewed directly. Content of knowledge and practice included 3 main contents: breast cancer, breast cancer prevention measures and early detection of breast cancer. Data was analyzed by SPSS software with 20.0 version. Results: the percentage of correct knowledge and practice on breast cancer prevention and early detection were $32,5 \%$ and $19,9 \%$ respectively. Conclusion: Knowledge and practice on prevention and early detection of breast cancer among women 18-60 years old in Can Tho city is quite low. Therefore, leaders of the Department of Health need to coordinate with the hospital to have appropriate interventions to increase knowledge and practice on prevention and early detection of breast cancer in women $18-60$ years.

Keywords: breast cancer prevention and early detection, knowledge and practice

\section{I. ĐăT VẤN ĐỀ}

Theo thống kê của Tổ chức $Y$ tế Thế giới (WHO), ước tính năm 2018 trên toàn thế giới sẽ 
có khoảng 2,1 triêu ca mới mắc ung thư vú (UTV), chiếm $11,6 \%$ trong các loại ung thư. Ung thư vú cũng đứng thứ 5 trong tổng số các loại ung thư gây tử vong (627.000 ca tử vong) chiếm $6,6 \%$ trong tổng số tử vong các loại ung thư. Tỷ lệ mắc ung thư vú cao nhất ở Úc/New Zealand (94,2/100.000), Bắc Âu (Vương quốc Anh, Thụy Điển, Phần Lan và Đan Mạch), Tây Âu (Bỉ có tỷ lê toàn cầu cao nhất là $92,6 / 100.000$, Hà Lan và Pháp), Nam Âu (Ý) và Bắc Mỹ [9].

Tại Việt nam, theo số liệu ghi nhận ung thư năm 2010, ung thư vú đứng hàng đầu ở nữ giới với tỷ lệ mắc chuẩn theo tuổi trung bình trong cả nước là 29,9/100.000 dân. Ước tính năm 2020, con số này là $38,1 / 100.000$. Đây thực sự là một gánh nặng cho bản thân người bệnh, gia đình bênh nhân và toàn xã hội [8]. Kinh nghiêm của nhiều quốc gia trên thế giới cho thấy việc tầm soát và phát hiện càng sớm sẽ giúp điêu trị bệnh càng đơn giản, hiệu quả điều trị càng cao, chi phí điều trị càng thấp [7]. Tuy nhiên phần lớn ung thư vú ở Việt Nam được chẩn đoán và nhập viện khi đã muộn, nguyên nhân chủ yếu là do thiếu hiểu biết và kỹ năng về phòng và phát hiện sớm ung thư vú [4],[7]. Do đó, kiến thức, thực hành phòng và phát hiện sớm ung thư vú có giá trị và ý nghĩa thực tiễn tại cộng đồng. Do đó, nghiên cứu thực hiện nhằm mục tiêu "Xác định tỷ lề kiến thức, thực hành đứng về phòng và phát hiện sớm ung thư vú ở phụ nữ 18-60 tuổ tại thành phố Cần Thơ năm 2020".

\section{II. ĐỐI TƯƠ'NG VÀ PHƯƠNG PHÁP NGHIÊN CỨU}

2.1 Đối tượng nghiên cứu: Phụ nữ 18-60 tuổi tại thành phố Cần Thơ trong thời gian nghiên cứu.

Tiêu chuẩn chọn vào: Phụ nữ 18-60 tuổi có hộ khẩu thường trú trên 6 tháng tại thành số Cần Thơ từ tháng 5 năm 2020 đến tháng 9 năm 2020; đồng ý tham gia nghiên cứu.

Tiêu chuẩn loại trừ: Bệnh nhân có các bệnh lý về tâm thần, thiểu năng trí tuệ. Đã được chẩn đoán mắc bệnh ung thư vú. Đã được tư vấn và hướng dẫn khám và phát hiện ung thư vú trước thời điểm nghiên cứu.

\subsection{Phương pháp nghiên cứu}

Thiết kế nghiên cứu: Nghiên cứu mô tả cắt ngang.

Cỡ mẫu trong nghiên cứu

- n: cõ mẫu

$$
n=\frac{Z_{1-a / 2}^{2} * p(1-p)}{d^{2}}
$$

- Z: hệ số tin cậy. Với độ tin cậy 95\% thì Z = 1,96
- p: Ước lượng tỷ lệ kiến thức và thực hành đúng của phụ nữ trong phòng và phát hiện sớm ung thư vú. Theo Nguyễn Thị Quế Lâm tỷ lệ kiênn thức chung là $\mathrm{p} 1=21,2 \%$; nghiên cứu Bùi Thị Duyên năm 2018, tỷ lệ phụ nữ có thực hành phát hiện sớm ung thư vú đạt p2 = 22,3\% [3], [5].

- d: sai số cho phép. Chọn $d=0,05$

Thay vào công thức ta được $n 1=257$ và $n 2$ $=267$. Chọn cõ̃ mẫu lớn nhất $\mathrm{n}=267$ phụ nữ 1860 tuổi. Cộng 5\% dự phòng mẫu, cõ mẫu nghiên cứu $n=281$; thực tế nghiên cứu trên $n=286$.

Phương pháp chọn mẫu: Chọn mẫu theo phương pháp phân tầng

Nội dung nghiên cứu: Kiến thức, thực hành về phòng và phát hiện sớm ung thư vú. Nội dung kiến thức gồm 3 nội dung chính là kiến thức về bệnh ung thư vú, các biện pháp phòng ngừa bệnh ung thư vú, kiến thức về phát hiện sớm ung thư vú. Thực hành đánh giá trên 2 nội dung là phòng bệnh ung thư vú và phát hiện sớm ung thư vú. Kiến thức và thực hành đúng: đạt $\geq 75 \%$ nội dung khảo sát. 20.0 .

Xử lý và phân tích số liệu: phần mền SPSS

\section{KẾT QUẢ NGHIÊN CỨU \\ 3.1. Đặc điểm chung}

Bảng 1. Đặc điểm về tuổi, giới

\begin{tabular}{|c|c|c|c|}
\hline \multicolumn{2}{|c|}{ Đặc điếm chung } & Tần số & Tỷ lệ\% \\
\hline \multirow{4}{*}{ Nhóm tuổi } & $18-24$ & 64 & 22,4 \\
\cline { 2 - 4 } & $25-29$ & 31 & 10,8 \\
\cline { 2 - 4 } & $30-39$ & 65 & 22,7 \\
\cline { 2 - 4 } & $40-49$ & 58 & 20,3 \\
\cline { 2 - 4 } & $50-60$ & 68 & 23,8 \\
\hline \multicolumn{2}{|c|}{ Trung binh } & \multicolumn{2}{|c|}{$37,9 \pm 12,9$} \\
\hline
\end{tabular}

Tuối trung bình của đối tượng là $37,9 \pm 12,9$; phân bố tương đối đều ở các nhóm tuổi từ 2023\% ở nhóm 18-24; 30-39; 40-49 và 50-60 tuổi; nhóm thấp nhất là 25-29 tuổi với 10,8\%.

Bảng 2. Địa dư, dân tộc

\begin{tabular}{|c|c|c|c|}
\hline \multicolumn{2}{|c|}{ Địa dư, dân tộc } & Tân số & Tỷ lệ \% \\
\hline \multirow{2}{*}{ Địa dư } & Thành thị & 163 & 57,0 \\
\cline { 2 - 4 } & Nông thôn & 123 & 43,0 \\
\hline \multirow{3}{*}{ Dân tộc } & Kinh & 267 & 93,4 \\
\cline { 2 - 4 } & Khmer & 11 & 3,8 \\
\cline { 2 - 4 } & Hoa & 8 & 2,8 \\
\hline
\end{tabular}

Thành thị chiếm 57\%; dân tộc Kinh chiếm 93,4\%.

3.2. Kiến thức về phòng và phát hiện sớm ung thư vú

Bảng 3. Kiến thức về bệnh ung thư vú $(n=286)$

\begin{tabular}{|c|c|c|}
\hline $\begin{array}{c}\text { Kiến thức đúng về bệnh } \\
\text { ung thư vú }\end{array}$ & $\begin{array}{c}\text { Tân } \\
\text { số }\end{array}$ & $\begin{array}{c}\text { Tỷ lệ } \\
(\%)\end{array}$ \\
\hline Ung thư vú là bệnh phố biến & 208 & 72,7 \\
\hline
\end{tabular}




\begin{tabular}{|c|c|c|}
\hline ở phụ nữ & & \\
\hline $\begin{array}{l}\text { Yếu tố làm tăng nguy cơ ung } \\
\text { thư vú }\end{array}$ & 56 & 19,6 \\
\hline Vaccin phòng & 243 & 85,0 \\
\hline Biện pháp phòng ngữa ung & 120 & 42,0 \\
\hline
\end{tabular}

Kiến thức đúng về bênh ung thư vú từ 15$85 \%$; cao nhất là kiến thức về ung thư vú chưa có vaccine phòng bệnh chiếm $85 \%$.

Bảng 4. Kiến thức về phát hiện sớm ung thư vú qua tự khám vú và khám chuyên khoa $(n=286)$

\begin{tabular}{|c|c|c|}
\hline $\begin{array}{c}\text { Kiến thức đúng phát hiện } \\
\text { sớm ung thư vú }\end{array}$ & $\begin{array}{c}\text { Tân } \\
\text { số }\end{array}$ & $\begin{array}{c}\text { Tỷ lệ } \\
\text { (\%) }\end{array}$ \\
\hline Biết phương pháp tự khám vú & 160 & 55,9 \\
\hline $\begin{array}{c}\text { Khám vú tại cơ sớ y tế (CSYT) } \\
\text { chuyên khoa }\end{array}$ & 228 & 79,7 \\
\hline $\begin{array}{c}\text { Độ tuối bắt đâu khám vú tại } \\
\text { CSYT chuyên khoa }\end{array}$ & 62 & 21,7 \\
\hline $\begin{array}{c}\text { Thời gian định kỳ khám vú tại } \\
\text { CSYT chuyên khoa }\end{array}$ & 73 & 25,5 \\
\hline $\begin{array}{c}\text { Các lợi ích của khám vú tại } \\
\text { CSYT chuyên khoa }\end{array}$ & 72 & 25,2 \\
\hline
\end{tabular}

Kiến thức đúng về phát hiên sớm ung thư vú, có $55,9 \%$ biết về phương pháp tự khám vú, kiến thức về khám vú để phát hiện ung thư vú tại cơ sở y tế chuyên khoa dao động từ 21-79\%.

Bảng 5. Kiến thức về chụp Xquang tuyến vú $(n=286)$

\begin{tabular}{|c|c|c|}
\hline $\begin{array}{c}\text { Kiến thức đúng chụp } \\
\text { Xquang tuyến vú }\end{array}$ & $\begin{array}{c}\text { Tân } \\
\text { số }\end{array}$ & $\begin{array}{c}\text { Tỷ lệ } \\
\text { (\%) }\end{array}$ \\
\hline $\begin{array}{c}\text { Xquang tuyến vú } \\
\text { Độ tuối bắt đâu chụp } \\
\text { Xquang tuyến vú }\end{array}$ & 136 & 47,6 \\
\hline $\begin{array}{c}\text { Thời gian định kỳ chụp } \\
\text { Xquang tuyến vú }\end{array}$ & 54 & 10,1 \\
\hline $\begin{array}{c}\text { Các lợi ích của chụp } \\
\text { Xquang tuyến vú }\end{array}$ & 61 & 21,3 \\
\hline
\end{tabular}

Kiến thức đúng về chụp Xquang tuyến vú chiếm tỷ lệ từ 10,1-47\%; trong đó, kiến thức đúng cao nhất là biết nên chup Xquang tuyến vú trong sàng lọc bệnh ung thư vú chiếm 47,6\%; kiến thức đúng về độ tuổi chụp Xquang tuyến vú chỉ chiếm 10,1\%; thời gian định kỳ chụp Xquang tuyến vú chiếm 18,9\%; các lợi ích khám Xquang tuyến vú chiếm $21,3 \%$.

Bảng 6. Đánh giá kiến thức về phòng và phát hiên sớm ung thư vú của phu nữ 1860 tuổi

\begin{tabular}{|c|c|c|}
\hline Kiến thức chung & Tân số & Tỷ lệ (\%) \\
\hline Đúng & 93 & 32,5 \\
\hline Chưa đúng & 193 & 67,5 \\
\hline Tống & 286 & 100,0 \\
\hline
\end{tabular}

Kiến thức chung đúng về phòng và phát hiện sớm ung thư vú chiếm 32,5\%; không đúng chiếm $67,5 \%$.

3.3. Thực hành về phòng và phát hiện sớm ung thư vú

Bảng 7. Thức hành đúng về phòng ngừa bệnh ung thư vú

\begin{tabular}{|c|c|c|}
\hline $\begin{array}{c}\text { Thực hành đúng phòng } \\
\text { ngửa bệnh ung thư vú }\end{array}$ & $\begin{array}{c}\text { Tân } \\
\text { số }\end{array}$ & $\begin{array}{c}\text { Tỷ lệ } \\
\text { (\%) }\end{array}$ \\
\hline Hạn chế yếu tố nguy cơ & 269 & 94,1 \\
\hline Kiếm soát chế độ ăn & 203 & 71,0 \\
\hline $\begin{array}{c}\text { Hoạt động thể dục thể thao, } \\
\text { kiểm soát cân nặng }\end{array}$ & 53 & 18,5 \\
\hline $\begin{array}{c}\text { Thực hành về phát hiện sớm } \\
\text { ung thư vú }\end{array}$ & 59 & 20,6 \\
\hline
\end{tabular}

Thực hành về hạn chế yếu tố nguy cơ đúng chiếm $94,1 \%$; $71 \%$ có thực hành kiểm soát chế độ ăn, $18,5 \%$ có thực hành đúng về thể dục thể thao và kiểm soát cân nặng; $20,6 \%$ thực hành đúng về phát hiện sớm ung thư vú.

Bảng 8. Đánh giá thực hành về phòng và phát hiện sớm ung thư vú của phụ nữ 1860 tuối

\begin{tabular}{|c|c|c|}
\hline Thực hành chung & Tân số & Tỷ lệ (\%) \\
\hline Đúng & 57 & 19,9 \\
\hline Chưa đúng & 229 & 80,1 \\
\hline Tống & 286 & 100,0 \\
\hline
\end{tabular}

Thực hành chung đúng về phòng và phát hiện sớm ung thư vú chiếm 19,9\%.

\section{BÀN LUẬN}

4.1. Đặc điểm chung. Tuổi trung bình của đối tượng là $37,9 \pm 12,9$; phân bố tương đối đều ở các nhóm tuổi từ 20-23\% ở nhóm 18-24; 3039; 40-49 và 50-60 tuổi; nhóm thấp nhất là $25-29$ tuổi với $10,8 \%$. Chủ yếu đối tượng nghiên cứu tập trung >40 tuổi. Đây là độ tuổi có nguy cơ mắc UTV tăng cao, do vậy việc nâng nhận thức cho phụ nữ có thể sẽ đem lại tác động tích cực đến việc phòng và phát hiện sớm bệnh, góp phần tăng hiệu quả điều trị. Tuối thấp hơn so với nghiên cứu của Deniz và cộng sự thực hiện với đối tượng nghiên cứu có độ tuổi trung bình là 45,6 $\pm 11,4$, với nhóm <45 tuổi chiếm $51,3 \%$. Đa số đối tượng ở nghiên cứu của chúng tôi sinh sống ở thành thị chiếm 57\%; dân tộc Kinh chiếm 93,4\%.

4.2. Kiến thức, thực hành về phòng và phát hiện sớm ung thư vú ở phụ nữ 18-60 tuổi

4.2.1. Kiến thức. Việc trang bị kiến thức, giúp phụ nữ có hiểu biết đúng về các yếu tố nguy cớ, biết về độ tuổi dễ mắc hay những việc có thể làm để thay đổi, hạn chế nguy cơ mắc UTV là vô cùng quan trọng. Kiến thức đúng về bệnh ung thư vú từ 15-85\%; cao nhất là kiến 
thức về ung thư vú chưa có vaccine phòng bênh chiếm $85 \%$; thấp nhất là kiến thức về yếu tố làm tăng nguy ơ ung thư vú với tỷ lệ $19,6 \%$. Kết quả này thấp hơn so với kết quả nghiên cứu của Nguyễn Hữu Châu thực hiện năm 2015 trên 1.200 phụ nữ có $67,9 \%$ có kiến thức đúng về bệnh UTV [2] và nghiên cứu của Nguyễn Ngọc Bích trên 600 phu nữ tai môt xã có $42,4 \%$ có kiến thức đat về dư phòng UTV [1]. Nghiên cứu của tác giả Bùi Thị Duyên (2018) thực hiện năm tại Thanh Hóa với tỷ lệ là 90,7\% [3]. Sự khác nhau này có thể là do sư khác nhau giữa đăc điểm của đối tượng nghiên cứu khi nghiên cứu của Nguyễn Hữu Châu, nghiên cứu của Nguyễn Ngọc Bích và nghiên cứu của Bùi Thị Duyên được thực hiện trên nhóm phu nữ ở nhiều độ tuổi, nghề nghiệp, trình độ học vấn khác nhau trong cộng đồng.

ớ nghiên cứu của chúng tôi, kiến thức về yếu tố nguy cơ của bênh chiếm tỷ lệ thấp nhất, chỉ có 19,6\% phụ nữ có kiến thức đúng về nội dung này. Kết quả này cho thấy, những đối tượng phụ nữ chưa nhận thức tốt về những nguy cơ nào có thể gây tăng ung thư vú, cũng không biết rằng mình có thể làm gì để hạn chế những rủi ro. Chính vì vậy, những chương trình truyền thông, nâng cao kiến thức về bênh UTV là rất cần thiết đối với phu nữ 18-60 tuổi, giúp ho có nhận thức đúng về bềnh và có thực hành sớm để hạn chế rủi ro từ những yếu tố nguy cơ. Tương tự nghiên cứu của Đào Trung Nguyên [6] năm 2019 về kiến thức và thực hành phát hiện sớm ung thư vú ở nữ công nhân cho thấy kiến thức của đối tượng này về nội dung yếu tố nguy cơ khá thấp; trong 259 đối tương tham gia nghiên cứu, chỉ có $23,9 \%$ có kiến thức đạt về các yếu tố nguy cơ mắc UTV; $11,6 \%$ biết đúng độ tuổi dễ mắc UTV là trên 35 tuổi; $21,6 \%$ biết rằng không có vaccine để phòng ngừa UTV và $32,8 \%$ có kiến thức đạt về các biện pháp làm giảm nguy cơ mắc UTV.

Ngoài việc phòng bệnh UTV thì phụ nữ cũng rất cần phải biết những phương pháp để phát hiên sớm UTV, nhằm phát hiện ra sớm những bất thường ở vú, giúp cho việc chẩn đoán và điều trị đạt hiệu quả cao. Ba phương pháp phát hiện sớm UTV được nghiên cứu này đánh giá là các phương pháp thường sử dụng, bao gồm: tự khám vú, khám vú tại cơ sở y tế chuyên khoa và X-quang tuyến vú. Nghiên cứu của chúng tôi ghi nhận kiến thức đúng về phát hiện sớm ung thư vú, có $55,9 \%$ biết về phương pháp tự khám vú. Tỷ lệ này gần tương tự với nghiên cứu của tác giả Bùi Thị Duyên (2018) là 58,7\% [3]. So với nghiên cứu của Đào Trung Nguyên [6] có tới
56,8\% nữ công nhân chưa từng nghe đến phương pháp này và chỉ có $43,2 \%$ đã từng được nghe.

Khám vú tại cơ sở y tế chuyên khoa là phương pháp khám vú lâm sàng do nhân viên y tế thực hiện nhằm phát hiên ung thư vú ở giai đoạn sớm và thường được thực hiện ở các nước đang phát triển nơi mà UTV đang tăng và phương pháp chụp X-quang vú chưa phát triển manh. Kết quả nghiên cứu của chúng tôi cho thấy, kiến thức đúng về khám vú tại cơ sở y tế chuyên khoa dao động từ 21-79\%; trong đó, cao nhất là $79,7 \%$ đối tượng biết cần khám vú tại CSYT chuyên khoa; kiến thức về thời gian khám định kỳ và lợi ích của khám vú chuyên khoa trung bình $25 \% ; 21,7 \%$ có kiến thức đúng về độ tuổi bắt đầu khám vú.

Kết quả khá phù hợp so với nghiên cứu của Đào Trung Nguyên[6] ghi nhận chỉ có 20,5\% đối tượng nghiên cứu là chưa từng nghe tới phương pháp đi khám vú tại cơ sở y tế chuyên khoa, có tới 79,5\% đối tượng nghiên cứu đã từng nghe nói tới phương pháp này và có tới $76,4 \%$ có kiến thức chung về phương pháp khám vú tại cơ sở y tế chuyên khoa là đạt; tỷ lệ có kiến thức đúng về độ tuổi đi khám vú tại cơ sở y tế chuyên khoa là $52,9 \%$, về thời gian định kỳ khám là $5,8 \%$ và về lợi ích của khám vú tại cơ sở y tế chuyên khoa là $71,8 \%$.

ờ nghiên cứu chúng tôi, đối tượng có kiến thức đúng về chụp Xquang tuyến vú chiếm tỷ lệ từ 10,1-47\%; trong đó, kiến thức đúng cao nhất là biết nên chụp Xquang tuyến vú trong sàng lọc bêenh ung thư vú chiếm 47,6\%. Đào Trung Nguyên[6] có $65,3 \%$ là chưa từng nghe tới phương pháp chụp X-quang tuyến vú để phát hiện sớm bệnh ung thư vú, chỉ có $34,7 \%$ là đã từng nghe tới phương pháp này; như vây so với tác giả này thì đối tượng nghiên cứu của chúng tôi nghe và biết về phương pháp chụp X-quang tuyên vú để phát hiên sớm bênh ung thư vú cao hơn, có thể do nghiên cứu của chúng tôi nhiều đối tượng có trình độ đại học, sau đại học, cán bô là công chức, viên chức, cán bô hưu trí nên nhìn chung kiến thức sẽ tốt hơn đối tượng đa số là công nhân.

Kiến thức đúng về độ tuổi chụp Xquang tuyến vú chỉ chiếm 10,1\%; thời gian định kỳ chụp Xquang tuyến vú chiếm 18,9\%; các lợi ích khám Xquang tuyến vú chiếm $21,3 \%$. Kểt quả này tương tự với kết quả nghiên cứu của Tam Truong Donnelly và cộng sự (2014) cho thấy 26,4\% người tham gia nghiên cứu có nhận thức đúng theo khuyến cáo về chup $X$-quang tuyến vú. Tỷ lệ đối tượng nghiên cứu có kiến thức 
đúng về độ tuổi chụp X-Quang tuyến vú là $19,3 \%$, về thời gian định kỳ chụp là $7,3 \%$ và lợi ích của phương pháp chụp $X$-quang tuyến vú là $21,6 \%$, khá thấp. Tuy nhiên kết quả này cũng khá dế hiểu vì phương pháp chụp X-quang tuyến vú hiện tại vẫn còn mới và có chi phí khá cao sao với mức thu nhập bình quân ở nước ta. Chỉ những trường hợp sau khi khám phát hiện những bất thường ở vú và nhận được sự chỉ định của bác sỹ thì mới tiếp cận với phương pháp này.

Kiến thức chung đúng về phòng và phát hiện sớm ung thư vú chiếm 32,5\%; không đúng chiếm $67,5 \%$. Nhìn chung, kết quả nghiên cứu cho thấy kiến thức về phòng và phát hiện sớm ung thư vú ở phụ nữ 18-60 tuổi chưa cao. Như vậy, rất cần thiết để những chương trình truyền thông giáo dục sức khỏe về ung thư vú tại cộng đồng để nâng cao nhận thức của những phụ nữ độ tuổi 18-60 tuổi đối với việc phòng và phát hiện sớm bênh UTV.

4.2.3. Thực hành. Phòng bệnh UTV chính là những việc đởn giản trong cuộc sống hằng ngày mà phụ nữ có thể làm để hạn chế đi các yếu tố nguy cớ gây UTV. Thực hành về hạn chế yếu tố nguy cơ đúng chiếm $94,1 \% ; 71 \%$ có thực hành kiểm soát chế độ ăn, $18,5 \%$ có thực hành đúng về thể dục thể thao và kiểm soát cân nặng; $20,6 \%$ thực hành đúng về phát hiện sớm ung thư vú. Kểt quả trên cũng phù hợp với đặc trưng của đối tượng nghiên cứu. Do phong tục, tập quán sinh hoạt từ lâu nay, phụ nữ Việt Nam ít có thói quen hút thuốc lá, uống rượu bia và dung thuốc tránh thai hơn so với phụ nữ ở những nước khác. Nhưng đối tượng ở nghiên cứu của chúng tôi lại ít có sự quan tâm tới những vấn đề như luyện tập thể dục, thể thao hay chế độ ăn uống hẳng ngày có đảm bảo theo khuyến cáo không. Do nghiên cứu được thực hiện tại thành phố Cần Thơ, một thành phố lớn tại khu vực Đồng bằng sông cửu long, do đó, thực hành luyện tập, chế độ ăn có thể bị ảnh hưởng bởi điêu kiện kinh tế và thời gian lao động, cũng như cường độ làm việc cao hằng ngày của phụ nữ.

Tương tự, Đào Trung Nguyên [6] cho thấy thực hành chung về phòng bệnh UTV đạt chiếm tỷ lệ cũng khá cao là $79,9 \%$. Trong đó, $100 \%$ nữ công nhân không hút thuốc lá và uống rượu bia; $93,1 \%$ thực hành tốt hạn chễ dùng thuốc tránh thai. Tuy nhiên tỷ lệ hoạt động tập thể dục thường xuyên lại rất thấp, chỉ là $9,3 \%$; tỷ lệ nữ công nhân có chế độ ăn đủ rau xanh theo khuyến cáo và ít dầu mõ chỉ đạt ở mức trung bình, lần lượt là $53,3 \%$ và $40,9 \%$.

Nghiên cứu ghi nhận 20,6\% thực hành đúng về phát hiện sớm ung thư vú. Thực hành chung đúng về phòng và phát hiện sớm ung thư vú chiếm $19,9 \%$. Nhìn chung thực hành về phòng bệnh ung thư vú ở phụ nữ 18-60 tuổi thì khá tốt tưy nhiên, thực hành về khám sàng lọc phát hiện sớm ung thư vú thì khá thấp. Trong ba phương pháp sàng lọc khảo sát trong thực hành của nghiên cứu thì chụp X-quang tuyến vú là thăm dò được minh chứng rõ nhất trong khám sàng lọc UTV, có thể làm giảm nguy cơ bệnh nhân tử vong do UTV cho phép phát hiện bệnh rất sớm, ngay cả khi chưa có khối u. Tuy nhiên đây là phương pháp đắt tiền, chưa thể áp dụng sàng lọc cho tất cả phụ nữ ở Việt Nam, cũng như nhiêu nước trên thế giới. Cũ̃ng tương tự như vậy, tại Việt Nam việc đi khám vú lâm sàng tại các cở sở y tế chuyển khoa hiện tại vẫn là một phương pháp khá tốn kém đối với đa số những người lao động, cụ thể trong nghiên cứu này là những nữ công nhân may. Trong khi đó, tự khám vú lại là một phương pháp rất đơn giản, ít tốn kém, có thể áp dụng cho mọi đối tượng phụ nữ ở mọi tầng lớp xã hội. Đương nhiên, việc tự khám vú có thể kém chuẩn xác hơn, phát hiện muộn hơn so với 2 phương pháp kia. Nhưng việc tự khám thường xuyên sẽ giúp phát hiện sớm những bất thường ở vú, càng sớm bao nhiêu là càng tăng cơ hội điều trị, thời gian sông thêm cho bệnh nhân.

\section{KẾT LUÂ̂N}

Tỷ lệ kiến thức và thực hành đúng về phòng và phát hiện sớm ung thư vú lần lượt là $32,5 \%$ và $19,9 \%$. Trong đó, kiến thức về yếu tố làm tăng nguy cơ ung thư vú, độ tuổi và thời gian khám vú tại cơ sở y tế chuyên khoa cũng như chụp Xquang tuyến vú để phát hiện sớm ung thư vú đạt tỷ lệ chưa cao (10-25\%). Tương tự, thực hành về hoạt động thể dục thể thao, kiếm soát cân nặng; phát hiện sớm ung thư vú chỉ đạt tỷ lệ $18-20 \%$.

\section{TÀI LIẸU THAM KHẢO}

1. Nguyễn Ngọc Bích, Nguyễn Thị Kim Ngân, Trân Vũ (2008), "Một số yếu tố liên quan đến hành vi tự khám vú tại nhà ở phụ nữ độ tuổi 15-49 tại Xã Hưng Đạo Huyện Tứ Kỳ, tỉnh Hải Dương", Tạp chí Y tể công cộng, tập 11 (11), trang 38-43.

2. Nguyễn Hữu Chẩu (2015), "Nghiên cứu thực trạng kiến thức, thái độ, thực hành về bệnh ung thư vú ở phụ nữ $20-60$ tuối trên đia bàn tỉnh Khánh Hòa", Tạp chí Ung thư học Việt Nam, số 5/2015, tr.22-25.

3. Bùi Thị Duyên (2018). Kiến thức, thái độ và thực hành phát hiện sớm ung thư vú và một số yễu tố liển quan của phụ nữ từ 20 - 49 tuổi tại xã Cẩm Giang, Huyện Cẩm Thửy, Thanh Hóa, Luận văn thạc sỹ Y tế 
công cộng, Trường Đại học Y Hà Nội.

4. Nguyê̂n Bá Đức (2008). Phòng phát hiên sớm bệnh unng thư, NXB Y học Hà Nội.

5. Nguyê̂n Thị Quế Lâm (2017), Tìm hiểu một số yểu tố liên quan đến kiến thức, thái độ và thực hành về phòng chống bệnh ung thư vú ở phụ nữ thi xã Ninh Hòa, tỉnh Khánh Hòa, Đề tài cơ sở Trung tâm Truyền thông GDSK Khánh Hòa

6. Đào Trung Nguyên (2017), Kiến thức, thực hành về phòng và phát hiên sớm ung thư vú cúa phư nữ ở công ty cổ phân may 10 và một số yếu tố liên quan, Luận văn tốt nghiệp trường địa học $Y$ Hà Nội.
7. Đỗ Quốc Tiệp, Mai Xuân Sự, Phan Tiến Hoàng và công sư (2015). Nghiên cứu kiến thức của người dân về phòng chống bệnh ung thư tại Quảng Bình. Tạp chí Ung thư học Việt Nam, số 5/2015, tr.41-44.

8. Trân Văn Thuấn, Bùi Diệu, Nguyễn Bá Đức và cộng sự (2012). Gánh nặng bệnh ung thư và chiến lược phòng chống ung thư quốc gia đến năm 2020. Tap chí Ung thư học - Hội thảo quốc gia phòng chống ung thư lần thứ 16 tháng 10 năm 2012, Số 1 (2012).

9. Trân Văn Thuấn (2007), Sàng loc và phát hiện sớm bệnh ung thư vú, NXB Y học Hà Nội.

\title{
PHẪU THUÂTT NộI SOI ĐIỀU TRI UNG THƯ BUỒNG TRỨNG GIAI ĐOẠN SỚM TẠI BỆNH VIỆN UNG BƯỚU NGHỆ AN
}

\author{
Vũ Đình Giáp*, Nguyễn Khắc Tiến*, \\ Trần Bá Kiên*, Nguyễn Thế Trung*, Đoàn Thị Hồng Nhật*
}

TÓM TẮT

Mục tiêu: Nhận xét một số đặc điểm lâm sàng, cận lâm sàng và đánh giá kết quả sớm phẫu thuật nội soi điều trị ung thư biểu mô buồng trứng tại bệnh viện Ung bướu Nghê An. Phương pháp: Mô tả hồi cứu kết hợp tiến cứu. Kết quả: 28 bệnh nhân ung thư biểu mô buồng trứng với tuổi trung bình $50,5 \pm 11,8$. Kích thước khối u chiếm tỉ lệ cao nhất là $5-8 \mathrm{~cm}(57,14 \%)$. Giải phẫu bệnh ung thư biểu mô thanh dịch chiếm $42,86 \%$. Nồng độ CA12-5 tăng 71,43\% các trường hợp và có mối liển quan tới giai đoạn bệnh và thể GPB.Thời gian phẫu thuật trung bình $185 \pm 20,4$ phút (120-210 phút). Thời gian nằm viện sau mổ trung bình $8,78 \pm 1,73$ (7 - 14) ngày. Có 2 trường hợp võ u trong mố. Biến chứng sau mổ 3,57\% nhiểm trùng mỏm cắt và $3,57 \%$ nhiễm trùng vết mổ. Không có trường hợp nào chảy máu sau mổ. Kết Luận: Phẫu thuât nôi soi trong điều trị ung thư buồng trứng giai đoạn sớm là an toàn, hiệu quả, kết quả sớm đảm bảo về ung thư hoc. soi.

Tứ khóa: Ung thư buồng trứng, phẫu thuật nội

\section{SUMMARY}

OUTCOME OF LAPAROSCOPIC SURGERY FOR

EARLY STAGE OF EPITHELIAL OVARIAN CANCER IN NGHE AN ONCOLOGY HOSPITAL

Objective: To investigate amount of clinical and paraclinical features and to evaluate outcome of Laparoscopic surgery for stage1 of epithelial ovarian cancer in Nghê An Oncology Hospital. Methods: Retrospective- Prospective study. Results: Of the 28

*Bênh viên Ung Bướu Nghê An

Chịu trách nhiệm chính: Trần Bá Kiên

Email: kiente121311@gmail.com

Ngày nhận bài: 27.10 .2020

Ngày phản biên khoa hoc: 30.11.2020

Ngày duyệt bài: 9.12.2020 patients with mean ages is $50,5 \pm 11,8$. The serous epitheial carcinoma is confirmed by pathology $(42,86 \%)$. CA125 level is highly raised with $71,43 \%$ and is related to disease staging. Mean operative time is $185 \pm 20,4$ mins (120-210 mins). The mean time for recover postoperative period is $8,78 \pm 1,73(7-14)$ days. There are 2 cases of the intraoperative rupture tumor. The postoperative complications including: Vaginal cuff dehiscence Infection (3,57\%); wound infection $(3,57 \%)$ and Postoperative Hemorrhage is no recorded. Conclusions: Laparoscopic surgical staging of early ovarian cancer is safe, effective and and survival outcome seems acceptable.

Key words; epithelial ovarian cancer; laparoscopy

\section{I. ĐĂT VẤN ĐỀ}

Ung thư buồng trứng (UTBT) môt tronglà bênh ung thư nguyên nhân gây tử vong hàng đầu trong các bệnh UT phụ khoa. Bệnh chủ yếu xuất hiên ở tuổi mãn kinh, có khoảng hơn một nửa xuất hiện sau tuổi 60 [1],[2]. Theo GLOBOCAN 2018 thì trên thế giới năm 2018 có khoảng 295.414 ca ung thư buồng trứng và có 184.799 trường hợp tử vong do bệnh này tương ứng với tỷ lệ mới mắc và tử vong là $6,6 / 100.000$ dân và $3,9 / 100.000[1],[2]$. Tại Việt Nam số trường hợp mới mắc là 1500 và số trường hợp tử vong là $856[1]$.

Về điêuu tri, PT đóng vai trò chủ đạo, hóa chất bổ trợ sau PT được chỉ định ở phần lớn các giai đoạn ngoại trừ một số ít trường hợp giai đoạn sớm, nguy cơ thấp (giai đoạn $\mathrm{IA}, \mathrm{IB}$, độ mô học 1) [2], [3], [4]. Do chưa có một phương pháp sàng lọc thực sự có hiệu quả nên việc phát hiện và điều trị bệnh ở giai đoạn sớm là mong mỏi của tất cả các thầy thuốc UT phụ khoa cũng như là vấn đề then chốt trong cải thiện tiên lượng 